\title{
Conserving Water \& Biodiversity: Traditions of Sacred Groves in India
}

\author{
Mala Agarwal ${ }^{1}$
}

\begin{abstract}
Sacred groves, a wide spread phenomenon in cultures across the world, are often associated with religion \& culture, are instrumental in preserving biodiversity and nature without being questioned. Scattered all over India e.g. scrub forests in the Thar Desert of Rajasthan maintained by the Bishnois, Hariyali in Uttarakhand, Shinpin in Himachal Pradesh and associated with religion they are often sacrosanct. The sacred groves are self sustained ecosystem and conserve the endemic, endangered \& threatened species, medicinal plants and wide variety of cultivars. Water and soil conservation is the most well documented ecological service provided by the sacred groves that helps prevent flash floods and ensures supply of water in lean season in the desert of Rajasthan. Encountering threats like fragmentation, urbanization, and overexploitation now they need governmental support to exist e.g. Introduction of the 'Protected Area Category Community Reserves' under the Wild Life (Protection) Amendment Act, 2002.
\end{abstract}

Key words-W Wter conservation, eco-system, bio diversity, sacred groves.

\section{Introduction}

Sacred Groves are considered as "Sacred Natural Sites" (IUCN) [1]. These are the relic forest patches preserved in the name of religion \& culture. They extend from Asia, Africa, and Europe to America mostly in Africa and Asia [2]. In India, Groves are present from North-east Himalayan region, Western \& Eastern Ghats, Coastal region, Central Indian Plateau and Western desert [3].

Indian sacred groves have pre-Vedic origin. They are associated with indigenous / tribal communities who believe in divinity of nature and natural resources. The present thrust is on ecosystem functioning, ecological services and biodiversity conservation importance $[4,5]$.

There are more than a lakh such sacred groves in the country, have different names in different states, such as Devrai, Devban, Devbhumi, Gumpa etc. In Rajasthan, they are called Oran. Oran is derived from the Sanskrit word aranya, meaning forest. They are patches of jungle preserved in the name of local deities or saints.

\section{Origin}

Scholars are not unanimous about the origin of sacred groves. It is often believed that during shifting cultivation a part of the forest is left undisturbed. These areas might have developed as sacred groves [6]. Such sacred groves often protect

${ }^{1}$ Associate Professor, Department of Botany, BBD government PG College, Chimanpura (Affiliated with the University of Rajasthan, Jaipur, India) 
watersheds and water sources because of the people's belief that a deity located near the grove yields water for agriculture. The people in India and other tropical countries have been aware, from very early times, that their forests are ecologically fragile. Sacred groves uphold the notion that nature must be harnessed or used only within limits.'

In Rajasthan, water is scarce for farming, animal husbandry and drinking purposes. Forests reduce the runoff and help in ground water recharge. The water thus becomes available in the Bawadi (step-well) or pool located within the sacred grove during the lean months. Water also brings minerals and fertilizers in rich quantities. People might have institutionalized these arrangements during the course of time by attaching sacred value to it, to make collective management easy and long-lasting. Sacred groves are the result of a complex ethno-scientific thinking of the local communities [7].

\section{Beliefs and practices}

In India, religious values have been saving our forests \& environment. Many communities have self-regulated and self-imposed rules regarding logging and hunting. They earmark certain patches of land, great refuge for native biodiversity in the name of the local forest deity. The presiding deity is local Hindu gods although some based on

Islamic and Buddhist origins, or folk religions. Due to community-supported initiative the flora and fauna of the area survives and thrives.

The Hindu tradition considers forests (Van/ Ban) to be of three types - Tapovan, Mahavan and Sreevan. Tapovan, inhabited by saints and rishis are forests associated with penance (Tapas). People could collect dry wood, leaves, forest produce and a limited amount of timber, though natural ecosystem would not be unnecessarily disturbed. Mahavan refers to the grand natural forests. Tapovan and Mahavan are considered to be a Raksha ("sanctuary") for flora and fauna as ordinary human beings are not allowed to enter these forests. Sreevan, which means, "forests of prosperity", consists of dense forests and groves.

Groves were considered as spaces of forests from where harvesting could be done and are associated with religious rites, festivals and recreation. This includes jhoola/ jhoolan. In the villages, Panchavati, or a cluster of five trees that represented the forests, were maintained. These trees represented the five elements of Earth, Water, Fire, Air and Space. [8]

\section{Location}

Sacred groves occur in a variety of places - from scrub forests in the Thar Desert of Rajasthan to rain forests in the Western Ghats of Kerala. Himachal Pradesh in the north and Kerala in the south are specifically known for their large numbers of sacred groves. 14,000 sacred groves have been reported from all over India, which act as reservoirs of rare fauna, \& flora, amid rural and even urban settings, the total number of sacred groves could be as high as 100,000. [9] 
C.P.R. Environmental Education Centre of the Government of India.* likely to increase.

\begin{tabular}{|c|c|c|}
\hline State & $\begin{array}{ll}\begin{array}{l}\text { No } \\
\text { groves }\end{array} & \text { of } \\
\end{array}$ & Local name \\
\hline Andra Pradesh & 691 & Pavitraskhetralu \\
\hline Arunachal Pradesh & 65 & Gumpa forests(attached to monasteries) \\
\hline Assam & 40 & Than, Madaico \\
\hline Chhattisgarh & $600^{*}$ & Sarna, Devlas,Mandar, Budhadev \\
\hline Goa & NA* & \\
\hline Gujarat & $29 *$ & \\
\hline Harayana & 248 & Beed or Bid, Bani, Bann, Janglat, hamlat \\
\hline Himachal Pradesh & 5000 & Deo bhumi \\
\hline Jharkhand & $21^{*}$ & Sarna, Jaherthan" in Godda of Jharkhand \\
\hline Karnataka & 1424 & Devarakadu,Devkad \\
\hline Kerala & 2000 & Kavu, Sarpa Kavu \\
\hline Maharashtra & 1600 & $\begin{array}{l}\text { Deorai/Devrai } \quad \text { (Pune,Ratnagiri,Raigarh,Kolhapur } \\
\text { districts) }\end{array}$ \\
\hline Manipur & 365 & Gamkhap, Maubak(sacred bamboo reserves) \\
\hline Meghalaya & 79 & Law kyntang,Law Lyngdoh \\
\hline Orissa & $322 *$ & Jahera, Thakuramma \\
\hline Pundichery & 108 & Kovil Kadu \\
\hline Rajasthan & $9 *$ & $\begin{array}{l}\text { Oran (Jaiselmer,Jodhpur,Bikaner),Kenkri (Ajmer), Vani } \\
\text { (Mewar),Shamlat deh, Devbani(Alwar), Jogmaya }\end{array}$ \\
\hline Sikkim & 56 & Gumpa forests( attached to monasteries) \\
\hline Tamil Nadu & 503 & Kovil Kadu \\
\hline Telangana & 65 & \\
\hline Uttarakhand & $18^{*}$ & Devbhumi, Bugyal(sacred alpine meadows) \\
\hline West Bengal & $670^{*}$ & Garamthan, Harithan, Jahera, Sabitrithan,Santalburithan \\
\hline
\end{tabular}

\begin{tabular}{|l|l|}
\hline District of Rajasthan & No of Groves \\
\hline Ajmer & 38 \\
\hline Alwar & 96 \\
\hline Barmer & 06 \\
\hline Bhilwara & 09 \\
\hline Bikaner & 05 \\
\hline Chittorgarh & 05 \\
\hline Dausa & 12 \\
\hline Jaipur & 26 \\
\hline Jaisalmair & 10 \\
\hline Jalore & 03 \\
\hline Sikar & 04 \\
\hline Sirohi & 02 \\
\hline Tonk & 03 \\
\hline Udaipur & 221 \\
\hline
\end{tabular}




\begin{tabular}{|l|l|l|l|}
\hline $\begin{array}{l}\text { S. } \\
\text { No. }\end{array}$ & Name of Site & District & Area (ha) \\
\hline 1. & Bhernath ka Oran & Kannoj Chittorgarh & 200 \\
\hline 2. & Kalka ji Orna & Danwara, Jodhpur & 163 \\
\hline 3. & Jogmaya Ka Oran & Jakhan Jodhpur & 5254 \\
\hline 4. & Kolu Pabuji & Nosar, Jodhpur & 9030 \\
\hline 5. & Charnai Mata & SukhMadhala, Jodhpur & 1045 \\
\hline 6. & Bhadariya oran & Lathi Jaiselmer & 27500 \\
\hline 7. & Ramdev ji ka Oran & Ramdevara Jaiselmer & 1250 \\
\hline 8. & Jogmaya Ka Oran & Jakhan Jodhpur & 5254 \\
\hline 9. & Kolu Pabuji & Nosar, Jodhpur & 9030 \\
\hline 10. & Charnai Mata & SukhMadhala, Jodhpur & 1045 \\
\hline
\end{tabular}

Rajasthan is vertically divided in two parts north to south, by the Aravali hills. To the west of the Aravalis is the Thar desert. There are about 25,000 Orans in Rajasthan covering an area of about 600,000 hectares. About 1100 major Oran's spread out in an area of more than 1, 00,000 hectares in Rajasthan providing livelihood to the rural population. The area under an Oran can vary from a few square meters to several hundred hectares. Bhadriya Oran in Jaisalmer districts has 15000 hectares, where as kundla's Oran has 7500 hectares in Barmer district. There are about 300 identified devbanis in and around Sariska National Park.

Dietrich Brandis, (1897)[10], gave initial information on sacred groves of Aravallis mostly occur in Pratapgarh and Banswara with abundance of Anogeissus pendula People do not cut wood for personal use and only dead and fallen trees are removed for use.

Sacred groves in Aravallis and Vindhyas can be classified into three major groups. In the first group are groves located near the village and close to a water source. Such groves are present at the top of small hillocks at Aravallis in Udaipur, in the Vindhyan tract of Kota Bundi, Baran and Jhalawar where people worship Bheruji, Bawsi and Mataji.

The second group of groves is dedicated to Lord Mahadeo. Vegetation of the entire or part of watershed is often protected as groves. Large trees and a water source are the main characteristics of these groves. Water sources developed as open and step wells (Bawdi) may be seen at Ubeshwarji, kamalnath, Gautmeshwasji, Taneshwarji and Jhameshwarji in Udaipur. Sometimes both groups can also be found in the same village. The third type may be as a single tree. In Kota forest range several large trees of Ficus benghalensis due to the development of aerial and prop roots these trees look like a grove. The tradition of protecting Peepal, Gular and Bargad trees is also found in other states of India as well as from Asia and Africa.

In northern parts of Aravallis various other forms of sacred groves are maintained. These are known as kankar bani, rakhat bani, dev ouranya, vall and dev bani.

In desertified western Rajasthan large tract of tree-bearing orans are Ramdeora in Jaislamer and in Johpur. Species in most of the Orans are Prosopis cineraria, Zisyphus mauritiana and Salvadora sp, Zisyphus sp., Caparris aphylla and Calotropis procera.

These orans are filled with khejarli trees (Prosopis spicigera), deer, blackbuck and nilgai (Bluebull), are sacred to Bishnois. In the year 1730, in the village of Khejadli in Jodhpur district, 363 Bishnoi women gave up their lives to protect the trees, giving rise to the 
Chipko or "Hug a Tree" movement.

Mata Karni Devi Temple at Deshnoke village near Bikaner, the rodents, regarded as reincarnations of the goddess's devotees covered by Discovery and National Geographic channels. 2,100 hectare woodland near the temple is regarded sacred. Thousands of jhadberis (shrubs bearing berries) dot the area as cattle of the whole village graze freely. Hunting of animals, cutting of trees and even beating a bush to collect the berries are prohibited by Karni Mata Trust, which manages the Oran. Only wood for the purpose of cremation can be sourced from the Oran.

Important Orans in Sirohi, a semi-desert district in Rajasthan, include Pichheshwar Mahadeo near Pindwara, Voreshwar Mahadeo in Sheoganj, Sarneshwar Mahadeo near Sirohi (famous for its step-well), Mochal Mataji in Sheoganj (famous for Chinkara and Neelgai), Baleshwari Mataji Oran in Pesua village (famous for a very large Rayan tree) and Varada Hanuman ji which supports several old Prosopis cineraria trees.

Sacred groves or Orans are in various forms in Rajasthan as sacred groves (Oran, deora, malvan, deorai, rakhat bani, etc.), sacred corridors (deo ghats), temple forests (mandir van) and sacred gardens (baugh).

\section{The Baug: Sacred Gardens}

The Baug is an ethno-silvihorticultural garden planted near settlements for fruit, fodder, fuel wood, medicine and shade. They are the backbone of indigenous methods of drought prevention, acquisition of entitlements and food security. The biodiversity consists of utility trees such as Mangifera indica, Madhuca latifolia, Feronia limonia, Syzygium cuminii, Tamarindus indica, Phoenix etc. Such Baug are present in Udaipur, Kota (inside the Darrah Wildlife Sanctuary), Bundi, Baran and Jhalawar districts in Rajasthan. Sacred gardens are cultivated counterparts of sacred groves. Every garden has a sacred place dedicated to a village deity. Green felling is totally banned by the community, only dead and fallen wood is removed by the owner [11].

\section{Temple Forests}

Temple forests are found in India, China, Nepal and Thailand .[12] Temple forests are managed and maintained to serve the temple which includes economic, ecological, social and religious functions. Shri Nath ji temple in Udaipur, Rajasthan, India, has a large temple forest owned by the Temple Trust, and a sacred grove located in Gautameshwar forest block.

\section{Sacred Corridors}

Sacred Corridors are locally protected riverbanks by villagers in the name of Lord Shiva. Long stretches of Karai van or riparian forests are protected in several places along the river Chambal. In Kota Gaipernath and Garadia Mahadeo are Sacred corridors along the river Chambal attract hundreds of visitors during the annual religious fair dedicated to Lord Shiva. 


\section{Creating Groves: Planting and Deification of Neem by Gujjars}

The Gurjar people of Rajasthan have a unique practice of neem (Azadirachta indica) planting and worshipping as abode of God Devnarayan. A Gurjjar settlement near a water source, stream or river, with few huts and neem trees appears like a humaninhabited sacred grove. [13]. Size and frequency of neem trees can be a fairly reliable indicator of the age and history of the settlement. Gujjars being a pastoral community, the neem tree provide shade and air-conditioning for the livestock. Neem is also used as a medicine and seeds are a sustainable source of income.Kota district in Rajasthan, India, has about 600 Gujjar settlements, where an estimated 70,000 trees of various age and dimensions are thriving.

Kalyakui settlement, a sub village (Dhani) in Kota district of Rajasthan, has about 50 houses. Similarly Mangar Bani, last surviving natural forest of Delhi is protected by Gurjars of nearby area. [14]

\section{Sacred Grove Ecosystem}

Indian sacred groves represent a diverse spectrum of ecosystem. Groves are present amidst the barren landscape or grassland (e.g. in Meghalaya), hill slope (Nagoni in Himalaya), amidst the agricultural landscape (in West Bengal, Karnataka), coastal plain (e.g. Edayilekkadu in Kerala) and Rajasthan desert. In the groves regional ecosystem characteristics serve as models for researchers.

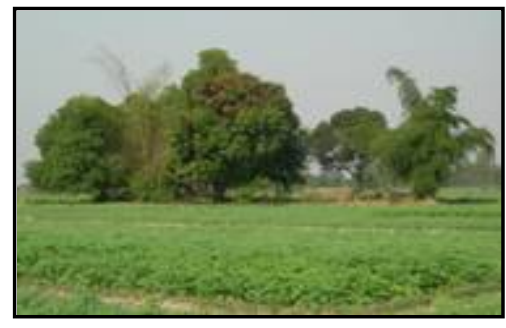

Grove in agricultural field

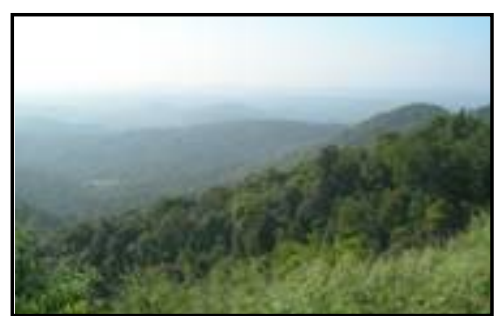

Grove in bill top area

\section{Biodiversity, ecological functions and resource use in sacred grove}

Sacred groves are considered as repository of local biodiversity with prevalence of endemic and rare threatened members [15-18]. The restriction in resource usage, undisturbed condition and suitable microclimate are the primary factors for this species richness.

Groves are independent distinct entity for biodiversity conservation and ecosystem functioning. It is true for large undisturbed groves which are self sustainable. Water conservation is perhaps the most well documented ecological service provided by the sacred groves. Highland groves (eg. Western Ghats and Himalayan region) are important for their soil and water conservation activities which are beneficial for the local inhabitants in terms of less soil erosion, preventing flash flood, supply of water in lean season etc[19-20\}. In Rajasthan desert, grove associated water bodies are important 
livelihood support for local people [7].

Orans are rich in bio-genetic diversity and are a refuge for wildlife. There are about 7.5 million pastoralists and 54.5 million livestock in Rajasthan, all dependent on the Orans. The Orans of the Bishnois in the desert district of Jodhpur are famous for the protection accorded to the Blackbuck and the Khejri (Indian Mesquite/Prosopis cineraria) tree, which are sacred to the Bishnois.

Resources that are traditionally obtained from sacred groves include fodder, fruits, dry fallen wood, seeds and ethno-medicine. They are the important source of water for traditional irrigation systems in Aravallis.

These areas also provide habitat, water and nest-sites for wildlife and birds. Several species of honey-bees nest in large trees in sacred groves. Peeple (Ficus religiosa), Bargad (Ficus benghalensis) and Gular (Ficus glomerata) trees are important for honey industry and local employment. Neem (Azadirachta indica) abound in sacred groves is an important ethno-botanical tree. Khajjur (Phoenis sp.) trees provide carbohydrate in the form of dry fruits and gives employment through the collection and sale of leaves used for broommaking. Khajjur groves located near Deola and Zhed in Udaipur are some important roosting places for fruit-bats. Several cavity-nesting birds excavate their nest in these trees and help farmers.

Some sacred groves support only one species of trees. e.g. Malpur, Rama Rathore, Valiakheda and Dhaikhera harbor teak trees (Tectona grandis), while Zed and Devla groves support Khajjur trees. Sacred groves in Vindhyas mainly consist of Dhok (Annogeissus pendula), Khakhra (Butea monosperma) in the hills and plains.

Sacred groves along the water streams mainly consist of Arjun (Terminalia arjuna), Jamun (Syzygium cuminii).Karneshwar Sacred, in the outskirts of Kota, is a grove located along the stream. It has a water pool where several species of fish, 53 species of birds and waders reside.Species of trees include Terminalia arjuna, Anogeissus pendula, Diospyros nelanoxylon, Syzygium cuminii, Mangifera indica, Ficus religiosa, Ficus benghalensis, Ficus glomerata etc. The Dardevi sacred grove in Kota supports lofty trees of Terminalia arjuna, Mitragyna parvifolia, Diospyros melanoxylon and Syzygium cuminii. Now, it is the only known natural habitat of Pandanus species in Kota District.

Jharan Mahadeo sacred grove in Jhalawar is situated along the stream leading to a large tank that ensures round the year supply of water to the city of Jhalawar. Rare plants include Bambusa hamiltonii and Scleichera oleosa. Today, it is a natural laboratory, a habitat island, a genebank, and a store-house of ethno-medicine. There is a perennial water spring.

\section{Uses}

Traditional uses: It acted as a repository for various ayurvedic medicines, a source of replenish able resources like fruits and honey. The vegetation cover helped to reduce soil erosion and preventing desertification in Rajasthan. The groves were often associated with ponds and streams that meet water requirements of local communities. They sometimes helped in recharging aquifers.

Modern uses: In modern times, sacred groves have become biodiversity hotspots, as 
various species seek refuge in the areas due to progressive habitat destruction, and hunting. Sacred groves often contain plant and animal species that have become extinct in neighboring areas. They therefore harbor great genetic diversity. Besides this, sacred groves in urban landscapes act as "lungs" to the city as well, providing much needed vegetation cover.

The Orans conserve valuable water in the ponds, reservoirs, step wells (bawdi), streams and springs that are an essential feature of the Oran. Since Rajasthan has access to barely $1 \%$ of India's water resources, all Orans contain a protected water source, thereby recharging groundwater and ensuring respectable water levels.

The Orans also protect local livelihoods and provide minor forest produce that are fuel wood, fodder for animals, grasses for basket-weaving, clay for pottery, leaves for making brooms, honey, fruits, seeds and medicinal plants for local use or the market.

Each Oran has a set of unwritten rules regarding the use of its resources. Tree-felling for any purpose other than funerals, repair of sacred structures or religious feasts is totally prohibited. Dry wood for domestic fuel wood requirements is permitted, but most households use cow dung, gas or wood provided by the Forest Department for their fuel requirements. In Orans seasonal or limited grazing is permitted. Large-scale extraction of any resource is strictly outlawed.

The survival of people and animals in this dry desert state has been possible because of their judicious management and use of natural resources, especially the Orans. The Oran is a traditional grassland management system which has also conserved the gene pool of indigenous species. Today, even as governments spend large amounts on protecting reserved forests and wildlife sanctuaries unsuccessfully, they are unable to provide the protection that existed in the ancient sacred groves, where local communities took direct charge of their own environmental needs. The public perception of the Oran is primarily as a common resource base. Unfortunately, as land becomes scarce, the Orans are also shrinking.

\section{Management and religious belief}

In arid Rajasthan, where summer temperatures regularly go up to $50^{\circ} \mathrm{C}$, Orans provide shade, fuel wood, fodder and even food and livelihood for humans and animals. They are controlled by local communities in a complex management system that has played an important role in the ecology, politics and history of Rajasthan. It is an excellent example how local communities protected their common resource base and provided food and water for animals in harsh and arid conditions.

Delineating an Oran is marked by a ceremony whereby Ganga water or saffron milk is poured around a specific area within the forest, which is thereafter declared to be an Oran or Dev bani (God's forest). This ceremony is called Doodh Jal or Kesar Chaanta, and marks the boundaries of the sacred grove.

In fact, all Orans are the focus of local religious activity, which may take the form of a shrine, temple or sacred stone. As sanctified space, they are the focus and meeting ground of local affairs: politics, crops, livestock and the management of the Oran itself are discussed here, and punishments for offences like encroachment and destructive extraction are levied around the temple or shrine. Puja (prayer) is regularly performed 
within the Oran, with special ceremonies held during times of hardship and drought. At the annual mela (festival) of the Orans, the local communities reaffirm their commitment to the forest and the deity. Van Samitis supervise the utilization and maintenance of the Oran, to ensure that there is no deviation from the village-appointed rules.

A unique aspect of Oran management is the presence of a mahatma, baba or priest with a socio-cultural role. The mahatma like a watchman resides in the Oran and keeps watch over the forest and its inhabitants, in exchange for basic provisions from the community. He has been instrumental in fostering a reverence for nature and protecting the groves.

People do not harm sacred groves mainly because of socio-religious traditions and fear of the unknown, believing that those who cut or use an axe in a sacred grove may be harmed by the presiding deity. These beliefs might have strongly influenced conservation of sacred groves.

Usually, only fallen and ripe fruits are collected from the grove. It is possible that during severe drought some species may be lopped for fodder. Such species are Khakhra (Butea monosperma), Neem (Azadirachta indica), Godal (Lannea coroman-delica), Ber (Zizyphus mauritiana), Salar (Boswellia serrata), Khejadi (Prospis cineraria), Ronjh (Acacia leucophloea), Bargad (Ficus benghalensis) etc.

Pipal (Ficus religiosa) trees growing on the bunds of Johad (sacred ponds) in Alwar district are lopped for fodder. Water from Johad is used for limited irrigation and for drinking purposes for livestock. Other sacred groves provide water for drinking and limited irrigation.

Ubeshwar Mahadeo, an important sacred grove near Udaipur has a temple dedicated to Lord Shiva. It is situated close to a water stream and thus serves as a watering and resting place for people and livestock. No cowdung is removed from the area, and is allowed to decay or dry. The dried dung cakes are used to cook bati (ball-like local bread) by villagers and pilgrims who visit the temple. The arrangement ensures the sanctity of the grove and provides ample stock of fuel to all.

At the Jugrawar Roondh Oran, $100 \mathrm{~km}$ away from Alwar, every family has to contribute a sack (about 5 kilos) of grain from the first harvest to the Oran. This is stored in a small bunker and the Baba who lives therein spreads it out on a platform every morning and evening. Proud peacocks, unmindful of human visitors, strut about boldly to feed among deer, squirrels and several varieties of birds.

\section{Threats to grove system}

Threats to the grove include urbanization, over-exploitation of resources, environmental destruction, fragmentation, area shrinkage and degradation, alien species invasion, grazing, resource extraction submergence, clear felling, mining, quarry, encroachment and other depletive factors etc. Moreover, changes in social structure, resource management also affect grove tradition simultaneously.

In Rajasthan a part of Ubeshwarji sacred grove was destroyed by submergence because of construction of an anicut across the stream flowing through the grove. Taneshwarji sacred grove is threatened by mining and stone quarrying. Amrakji sacred grove, that 
protects a large specimen of Holoptelia integrifolia and provides drinking water to livestock reared by people in a nearby village, was threat-ened by encroachers to set up industries around the grove. Malpur sacred grove, in a private land holding, was clear felled because it contains valuable teak-wood.

Orans are also threatened because of increasing pressure from population and livestock. Unfortunately, these lands have not even been declared as forest lands, hence effective legislation is not applied in the case of offenders. Eroding community values Lack of faith in the younger generation have made the matter worse.

\section{Conservation of Sacred grove tradition}

The current resurgence of interest in the system is mostly due to its invaluable contribution towards conservation of biodiversity and important ecosystem services. International and national bodies have taken various measures to safeguard the grove tradition from the threat of extinction. In India, state forest departments, Non Governmental Organizations (NGOs), village level committees, academics and researchers are working with various aspects as well as are actively involved in grove conservation works[21]. Conservation activities are mainly of three types.

\section{a) Strengthening the existing conservation activities of the villagers}

Villagers with support from forest department, NGOs can protect the groves at their vicinity. Initiatives like prevention of cattle grazing, restriction on manure collection, removal of invasive plants, complete ban on infrastructure development etc. can be taken as a precaution for saving grove biota and ecological activities. Incentives could be made in the form of carbon credit, ecotourism and for monitoring activities with emphasis on local condition and requirement.

\section{b) Restoration of the degraded sacred groves}

Restoration activities include planting native species, protection for seedlings and saplings, nursery establishment for rare, endemic plants, measures for soil and water conservation etc. These dependent on interests / awareness of local community, livelihood benefits as well as proper scientific assessment / monitoring of the conservation activities.

\section{c) Landscape level approach}

Landscape approach is wider and requires thorough knowledge on ecological processes going on in grove system and its surroundings, interactions of grove biota and issues of landscape ecology. Ecosystem services like pollination, seed dispersal, nutrient cycling and soil and water conservation are usually operated in larger spatial extent combining different land use types at different times and therefore, require an integrated approach at landscape level. Considering the present fragmented conditions of the groves, they can be used as repositories of endemic plants, soil seed bank, connective corridor for birds and animals in human dominated landscapes. Therefore, it requires 
combined and holistic approach to conserve the grove tradition in landscape level.

\section{Conclusion}

Groves are age old traditional nature conservation practices adopted by the communities throughout the world. Perhaps this is the first approach by the rural people to protect the nature from overexploitation long before the term "conservation" coined. The need of the hour is to aware people for its conservation and management as they would definitely benefit from restoration of sacred groves as ethno medicines, dead and fallen wood, seed collections and limited irrigation from the water source near the grove. The Rajasthan State Forest Policy (2010) acknowledges the importance of the orans / devbanis as "islands of good forests where religious faith linked with conservation and repositories of rich biodiversity."

Although these Orans are local community lands, the legal ownership lies with the state revenue department. The traditional practice of protecting these Orans and having the local community as the custodians can provide an effective tool for ensuring conservation through community participation. It's important to have a planned holistic approach with local commitment, extensive community awareness as well as supportive policies and laws.

\section{References}

Oviedo, G., Jeanrenaud, S. \& Otegui, M. (2005). Protecting Sacred Natural Sites of Indigenous and Traditional Peoples: an IUCN Perspective. Gland, Switzerland.

Hughes, J.D. \& Chandran, M.D.S. (1998). Sacred groves around the Earth: An overview. Pp. 69-86 in Ramakrishnan, P.S., Saxena, K.G. and Chandrashekara, U.M. (eds.). Conserving the sacred for biodiversity management. Oxford \& IBH Publishing Co. Pvt. Ltd. New Delhi, Kolkata.

Malhotra K.C., Gokhale, Y., Chatterjee, S. \& Srivastava, S. (2001). Cultural and ecological dimensions of sacred groves in India. Report. Indian National Science Academy, New Delhi \& Indira Gandhi Rashtriya Manav Sangrahalaya, Bhopal.

Chandrashekara, U.M. \& Ramakrishnan, P.S. (1994). Successional patterns and gap phase dynamics of a humid tropical forest of the Western Ghats of Kerala, India: ground vegetation, biomass, productivity and nutrient cycling. Forest Ecology and Management, 70: 23-40.

Arunachalam, A., Arunachalam, K., Pandey, H.N. \& Tripathi, R.S. (1998). Fine litter fall and nutrient dynamics during forest regrowth in the humid subtropics of north-eastern India. Forest Ecology and Management 110, 209-219.

Gadgil, M., and Vartak, V.D. (1976).Sacred Groves in India: A plea for continuous conservation. Journal of the Bombay natural Society,72,314-320.

Pandey, D.N., Sacred forestry: The case of Rajasthan, India. Retrieved from http://www. infinityfoundation.com/ECITsacredforestryfarmeset.htm.

Ranchor P. (2002). Vedic ecology: Practical wisdom for surviving the 21st Century, Mandala Publishing, Novato, CA.

Ramchandra, GUHA .(2000). The Uniquiet. Woods, University of California Press. Brandis, D. (1897). Indian Foestry. Oriental University Institute.

Kapoor, R. P., \& Pandey D. N. (1998). Indigenous Knowledge on Silvicultural Enrichment in Rajasthan, Wateland News.

Chandrakant, M. G., Gilless, G and Nagaraja. 1990. Temple Forests in India’s Forest Development, Agro forestry systems, 11:199-211.

http://www.infinityfoundation.com/ECITsacredforestryfarmeset.htm.

http://www.ngtba.org/index.php/news 
Jamir, S.A., \& Pandey, H.N. (2003). Vascular plant diversity in the sacred groves of Jaintia Hills in northeast India. Biodiversity and Conservation 12,1497-1510.

Jayarajan, M. (2004). Sacred groves of north Malabar, Discussion paper no.92.Kerala Research Programme on Local on Local Level Development.Center for Local Level Development Stuies, Thiruvananthapuram.

Parthasarthy, N. and Karthikeyan, R. (1997). Plant biodiversity inventory and conservation of two tropical evergreen forests on the Coromanddel coast, south india. Biodiversity and Conservation 6,10631083.

Sukumaran, S and Raj, A.D.S. (2007). Rare, endemic, threatened trees and lianas in the sacred groves of Kanyakumari district. Indian Forester133,1254-1266.

Chandran, M.D.S. and Hughes, J.D. (1997). The sacred groves of south India: Ecology, traditional communities and religious change. Social Compass 44,413-427.

Singh, G. S., Rao K. S. \& Saxena, K. G. 1998. Eco-cultural analysis of sacred species and ecosystems in Chhakinal Watershe, Himachal Praesh. p301-314in Ramakrishnan, P. S., Saxena, K. G. and Chandrashekara, U. M. (eds.). Conserving the sacred for biodiversity management.Oxfor \& IBH Publishing Co. Pvt. Ltd. New Delhi, Kolkata.

Ray, R., Subash Chandran, M.D. and Ramachandra, T. N. Sacred Grove: Nature conservation tradition of ancient world. Retrieved from www.ces.iisc.ernet,in/ biodiversity/sahyadri-enews/.../article1.htm

Rathore, M. S. \& Shekhawat, N. S. (2011). Ethan botanical importance of orans-As a means of conserving Biodiversity. International Journal of Agricultural Science, Research and Technology in extension \& Education system1(4),195-200.

Blicharska, M., Mikusinski, G., Godbole, A. \& Sarnaik, J. (2013). Safeguarding biodiversity and ecosystem services of Sacred Groves-Experience from Northern western Ghats. International Journal of Biodiversity science, ecosystem services \& Management 9(4).

Kandari, L. S., Bisht, V. K., Bharadwaj, M. \& Thakur, A.K. (2014). Conservation and Management of sacred groves, myths and beliefs of tribal communities: A Case study from North India. Environmental system Research, 3:16. 